\title{
A giant ovarian cyst
}

\author{
Florent Valour, Erwan Oehler \\ Médecine Interne, Centre Hospitalier de Polynésie Française, Pirae, French Polynesia
}

Correspondence to Dr Florent Valour, florent.valour@chu-lyon.fr

\section{DESCRIPTION}

A 36-year-old woman with no medical history (gravida 0 , para 0) was admitted in the hospital because of progressive abdominal distension for several months. Physical examination revealed an enlargement of the abdomen, without other abnormalities. Laboratory findings were unremarkable. The diagnosis of ascites was proposed initially. A trans-parietal punction revealed a clear fluid, with no cells and a protein concentration of $1 \mathrm{~g} / \mathrm{l}$. The fluid was sent for culture and bacteriological testing and turned out to be sterile. Abdominal CT (figure 1) finally disclosed a large well-limited and encapsulated mass of $41 \times 42 \times 24 \mathrm{~cm}$ (asterisk), which seemed to originate from one of the ovaries, repressing the bowel (arrow) and the kidneys (arrow head), without signs of bowel obstruction or hydronephrosis. Tumour markers (CA19.9, CA125, $\alpha$-fetoprotein and carcinoembryonic antigen) were

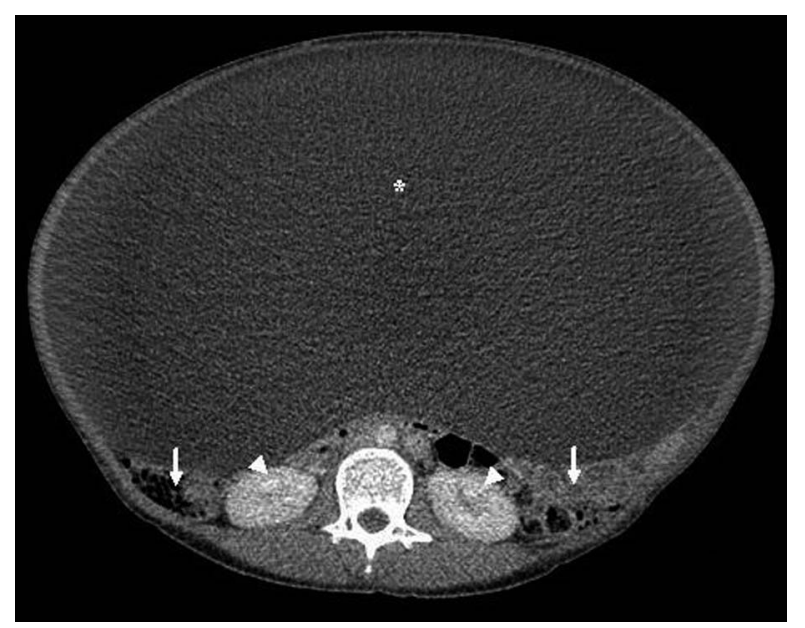

Figure 1 Abdominal CT showing a large ovarian cyst $(41 \times 42 \times 24 \mathrm{~cm}$, asterisk) repressing the bowel (arrows) and the kidneys (arrow heads). normal. A laparotomy disclosed a voluminous left ovarian cyst, which was punctured (231) and extracted during a left adnexectomy. Postoperative course was uneventful and the patient was discharged home. Pathological examination revealed a benign serous ovarian cystadenoma, with no evidence for malignancy.

Mainly described in the literature as case reports, ${ }^{1}$ giant ovarian cysts are often misdiagnosed as ascites following the initial clinical and even sonographic evaluation. The growth rate of ovarian cystadenoma, the most common benign ovarian neoplasm, is usually described as very slow. ${ }^{2}$ Similar conditions may arise from omentum, mesenterium and retroperitoneal structures. Giant ovarian cysts are usually managed by laparotomy and ovariectomy, although laparoscopic ovariectomy has been proposed. $^{3}$

\section{Learning points}

Giant ovarian cysts are frequently misdiagnosed as ascites and should always be considered in differential diagnosis of abdominal cavity enlargement.

- Initial sonographic evaluation can fail to diagnose correctly a giant ovarian cyst.

Competing interests None.

Patient consent Obtained.

\section{REFERENCES}

1. Young TH, Lee HS. Images in clinical medicine. Giant ovarian cyst. N Engl J Med 2008;358:e22.

2. Caspi B, Appelman Z, Rabinerson D, et al. The growth pattern of ovarian dermoid cysts: a prospective study in premenopausal and postmenopausal women. Fertil Steril 1997;68:501-5.

3. Vecchio R, Leanza V, Genovese F, et al. Conservative laparoscopic treatment of a benign giant ovarian cyst in a young woman. $J$ Laparoendosc Adv Surg Tech A 2009;19:647-8. 


\section{BMJ Case Reports}

Copyright 2012 BMJ Publishing Group. All rights reserved. For permission to reuse any of this content visit http://group.bmi.com/group/rights-licensing/permissions.

BMJ Case Report Fellows may re-use this article for personal use and teaching without any further permission.

Please cite this article as follows (you will need to access the article online to obtain the date of publication).

Valour F, Oehler E. A giant ovarian cyst. BMJ Case Reports 2012;10.1136/bcr-2012-007197, Published XXX

Become a Fellow of BMJ Case Reports today and you can:

- Submit as many cases as you like

- Enjoy fast sympathetic peer review and rapid publication of accepted articles

- Access all the published articles

- Re-use any of the published material for personal use and teaching without further permission

For information on Institutional Fellowships contact consortiasales@bmjgroup.com

Visit casereports.bmi.com for more articles like this and to become a Fellow 